\title{
CHARACTERIZATION OF KARANGNUNGGAL KAOLIN AS RAW MATERIALS FOR CERAMIC
}

\author{
KARAKTERISASI KAOLIN KARANGNUNGGAL UNTUK BAHAN \\ BAKU KERAMIK
}

\author{
WIDODO, SUBARI and BAGUS D. ERLANGGA \\ ${ }^{1}$ Research Center for Geotechnology, Indonesian Institute of Sciences \\ Komplek LIPI, Jalan Sangkuriang, Bandung, 40135, Indonesia \\ e-mail: widodohadiseputro@gmail.com \\ ${ }^{2}$ Center for Ceramic, Ministry of Industry \\ Jalan Jenderal Achmad Yani No. 392, Bandung, 40272, Indonesia
}

\begin{abstract}
Kaolin from Karangnunggal had been characterized. This kaolin has a brownish white in color and is associated with tuff. To identify characteristics, the samples was analyzed by XRD, optical microscope, AAS, and SEM. The results showed that the kaolin consisted of kaolinite, halloysite, cristobalite, dickite, muscovite, illit and hematit while petrographic analysis describes halloysite, kaolinite, dickite, and quartz. SEM analysis showed the crystal forms such as kaolinite, halloysite and dickite; while chemical analysis confirmed that kaolin composition comprised $\mathrm{SiO}_{2}=65.78 \%, \mathrm{Al}_{2} \mathrm{O}_{3}=19.55 \%$, $\mathrm{Fe}_{2} \mathrm{O}_{3}=0.90 \%$ and $\mathrm{LOI}=8.29 \%$. Based on characterization results Karangnunggal kaolin originated from tuff alteration. Referring to such properties, this kaolin can be used as raw material for white ceramic products such as sanitary, ceramic tiles and insulation.
\end{abstract}

Keywords: kaolin, XRD, petrographic, SEM, chemical, utilization

\begin{abstract}
ABSTRAK
Telah dilakukan karakterisasi percontoh kaolin daerah Karangnunggal. Percontoh kaolin berwarna putih kecoklatan berasosiasi dengan batuan sekitarnya berupa tuf. Untuk mengetahui karakteristik percontoh kaolin, dilakukan analisis XRD (X-Ray Diffractometer), petrografi, analisis kimia, dan SEM (Scaning Electron Microscope). Hasil masing-masing analisis percontoh kaolin sebagai berikut: analisis XRD menunjukan kandungan mineral berupa kaolinit, haloisit, kristobalit, dikit, muskovit, ilit dan hematit; analisis petrografi menggambarkan haloisit, kaolin, dikit, dan kuarsa; hasil analisis SEM memperlihatkan bentuk-bentuk kristal kaolinit, halosit dan dikit; dan hasil analisis kimia menunjukkan komposisi: $\mathrm{SiO}_{2}=65,78 \%, \mathrm{Al}_{2} \mathrm{O}_{3}=19,55 \%, \mathrm{Fe}_{2} \mathrm{O}_{3}=0,90 \%$ dan $\mathrm{LOI}$ (hilang pijar) $=8,29 \%$. Berdasarkan hasil analisis XRD, petrografi, dan SEM percontoh kaolin Karangnunggal terbentuk dari hasil alterasi batuan tuf yang menghasilkan endapan kaolin, sedangkan dari komposisi kimia, kandungan mineral dan sifat-sifat keramik; kaolin Karangnunggal dapat digunakan sebagai bahan baku untuk pembuatan produk keramik putih seperti sanitari, ubin keramik dan isolator.
\end{abstract}

Kata kunci: kaolin, XRD, petrogafi, SEM, kimia, pemanfaatan

\section{INTRODUCTION}

Indonesia has a lot of kaolin deposit showing variation in types and qualities. Kaolin is a rock consists of kaolinite mineral. Besides kaolinite, other minerals available within kaolin include dickite $\mathrm{Al}_{2} \mathrm{Si}_{2} \mathrm{O}_{5}[\mathrm{OH}]_{4}$, smectite $\left.(\mathrm{AIMg})_{4} \mathrm{Si}_{8} \mathrm{O}_{20}(\mathrm{OH})_{10}\right)$, illite,
$\left\{\left(\mathrm{K}, \mathrm{H}_{3} \mathrm{O}\right)(\mathrm{Al}, \mathrm{Mg}, \mathrm{Fe})_{2}(\mathrm{Si}, \mathrm{Al})_{4} \mathrm{O}_{10}(\mathrm{OH})_{2},\left(\mathrm{H}_{2} \mathrm{O}\right)\right\}$, and haloysite $\mathrm{Al}_{2} \mathrm{Si}_{2} \mathrm{O}_{5}[\mathrm{OH}]_{4}$ (Ajayi and Adefila, 2012). Kaolin is a hydrous aluminum silicate composition $\left(\begin{array}{llll}\mathrm{Al}_{2} \mathrm{O}_{3} & 2 \mathrm{SiO}_{2} & 2 \mathrm{H}_{2} \mathrm{O}\end{array}\right)$. Volcanic rocks and hydrothermal alteration are indicators of kaolin formation. 
In nature, there are three types of kaolin, namely residual kaolin (weathering the acid rocks such as granit and rhyolite), hydrothermal (alteration of alkali feldspar minerals by hot ground water) and sedimentary kaolins (deposition process from the origin to another sedimentation environment). The quality of kaolin is determined by chemical composition, mineral composition, brightness, shape and size of the granules. Kaolin in general can be used as raw materials for ceramics, paint, rubber, cosmetics, paper, and pesticides (Boch and Niepce, 2007; Kamseu et al., 2007).

Fialips et al. (1999) stated that kaolin crystallography and chemical characteristics of kaolin vary significantly and depend on the origin of the sediment deposits. Kaolin can be resulted from weathering the source rock (granite, feldspar, mica, and tuff) and was contaminated by other minor minerals to get different color. Cases et al. (1986) and Murray (2007) stated that detailed investigation of crystallography and mineralogy are needed to identify possible applications of the minerals within industry it was combined with chemical and physical characters. Identifying kaolinite minerals can be used X-ray diffraction analysis (Berry et al., 2006).

Specifically in ceramic industry, kaolin is usually used for manufacturing white ceramic such as tiles, sanitary and insulators. To make white ceramic hard porcelain is also used additional materials such as feldspar and silica with the ratio of $50 \%$ kaolin, $25 \%$ K-feldspar, and $25 \%$ silica (Fialips et al., 1999). In ceramic body, kaolin serves as a binder or plasticity, feldspar as a buster and silica as a filler. Such composition when burned at high temperature will produce mullite, but mainly depended on the use kaolin. Pure kaolin that well-ordered kaolinite can give good results of mulitisation after a burning process above $1.000^{\circ} \mathrm{C}$. For disordered kaolinite, mullite will be formed at temperatures of bigger than $1.200^{\circ} \mathrm{C}$ (Septawendar et al., 2007).

The purpose of this study is to determine kaolin characterization including mineral content, chemical analysis, grain size, moisture content, and the properties of the ceramic. This data are used to determine potential utilization of raw material for white ceramic (whiteware ceramics) such as tableware, sanitary and ceramic tiles. The expected benefits of this research is to increase the value-added of Karangnunggal kaolin.

\section{METHODOLOGY}

This research used primary and secondary data. The secondary data included internet, books, and existing literatures. This secondary data is used as supporting data during research activities in the field and laboratory to help find solutions in discussion. Primary data was obtained through two activities that is field and laboratory researches.

The field research consists of identification kaolin deposit and kaolin sampling; whereas laboratory research consists of chemical analysis, $X$ - ray diffraction ( XRD ), petrographic analysis, scanning electron microscope (SEM), water content, grain size, and properties of ceramic. The results of chemical analysis, XRD, petrographic, SEM, water content, and a large grain size is used to determine the quality kaolin as ceramic raw materials. To evaluate kaolin properties for ceramics, a specimen of $1 \mathrm{~cm}$ $x 1.5 \mathrm{~cm} \times 12 \mathrm{~cm}$ was made and burned at $1.050^{\circ} \mathrm{C}$ for 6 hours. The specimen was then characterized by measuring the dry shrinkage, shrinkage fuel, dry flexural strength, and thermal flexural strength.

Kaolin sample (Figure 1) were taken from Sarimanggu, Karangnunggal within coordinates of $7^{\circ} 36^{\prime} 45.7^{\prime \prime} \mathrm{S}$ and $108^{\circ} 7^{\prime}$ 36.9" E. The sediment was found in a lens form. The material showed yellowish-white in color, and it was slightly oxidized as well as rather plastic. The source rock was supposed to be from tuff breccia alteration. Kaolin also came due to sedimentary occurrences.

\section{RESULTS AND DISCUSSION}

Based on petrographic analysis Karangnunggal kaolin shows flow structure and gas holes due to the differences in lava density and viscosity, and gas evaporation as well. Based on petrografic analysis, its composition comprises colloform halloysite (45\%), flake dickite $(10 \%)$, kaolinite $6 \%$, iron oxide $5 \%$, feldspar $3 \%$, and quartz $2 \%$. The thin section of such a material is shown in Figure 2. 


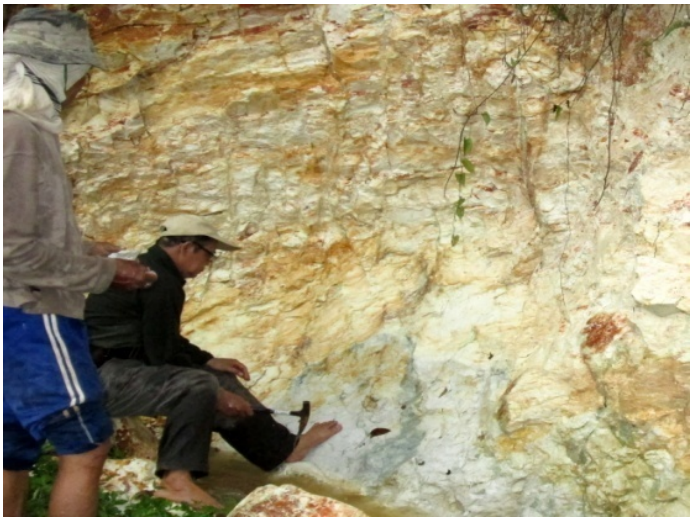

Figure 1. Karangnunggal kaolin deposit showing brownish white color

Kaolin for ceramics should contain the alkali $\left(\mathrm{K}_{2} \mathrm{O}\right.$ and $\left.\mathrm{Na}_{2} \mathrm{O}\right)$. Such materials help in sintering process due to its smelted character is not too strong. Quartz may control and enhance mechanical strength of the ceramics while the iron oxide results in color change of the ceramics to creamy brown after burning process.

Based on SEM analysis (Figure 3), Karangnunggal kaolin was composed by kaolinite, illite and halloysite. Kaolinite minerals looked like fan sheets while halloysite was in fine grains, and illite was in a flake shape. Karangnunggal kaolin was formed from feldspathic due to hydrothermal alteration and is associated with tuff, which then formed kaolin minerals such as kaolinite and halloysite. The content of illite in kaolin was smaller than that of kaolinite and halloysite. If the illite was greater than that of kaolinite, it would affect the color of white ceramic body due to the iron content within illite.

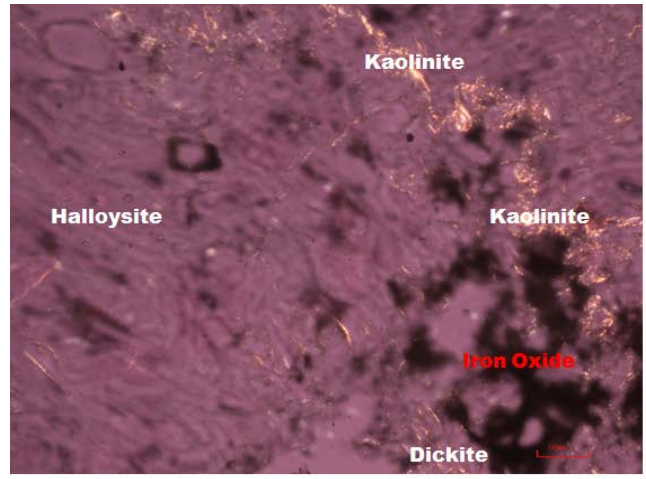

Cross Nico

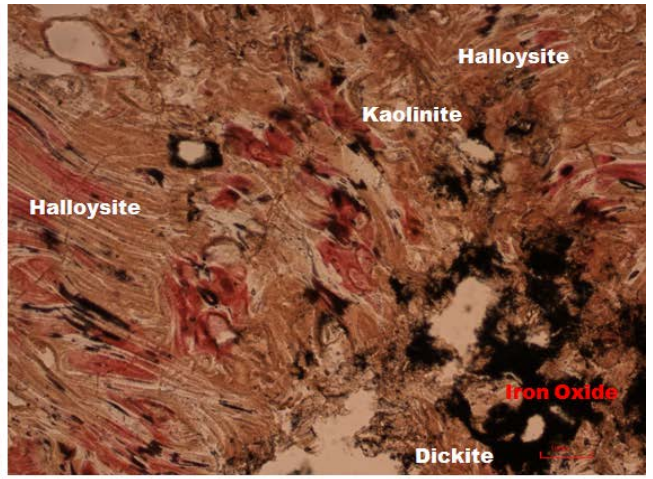

Parallel Nicol

Figure 2. Result of petrographic analysis for Karangnunggal kaolin

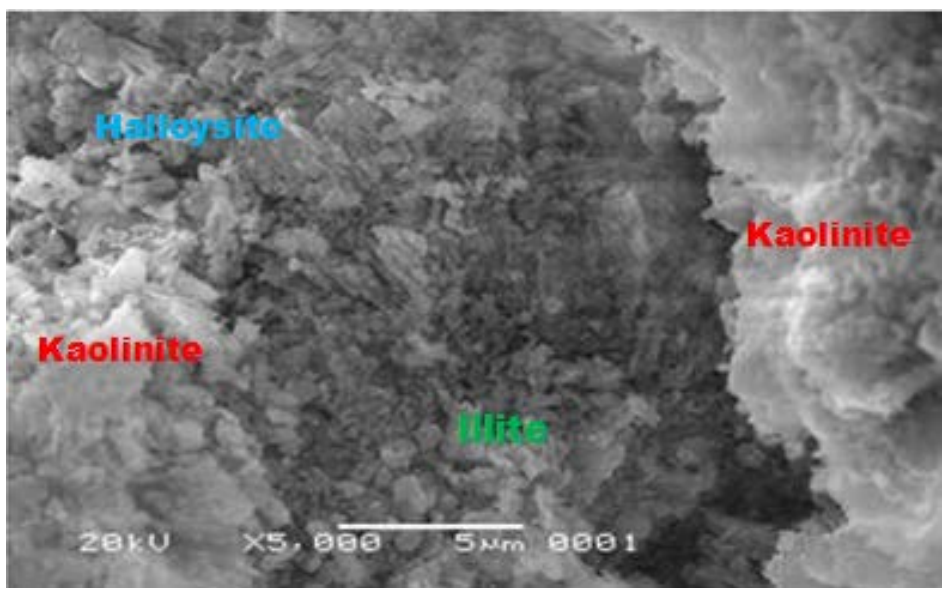

Figure 3. Result of SEM for Karangnunggal kaolin 
XRD analysis showed (Figure 4) that Karangnunggal kaolin contained kaolinite, dickite, halloysite, cristobalite, illite, muscovite and hematite. After peak calculation Karangnunggal kaolin comprised of dominant cristobalite (45.0\%), halloysite (25.2 \%), kaolinite (8.8\%), dickite, illite, and hematite with a small peak intensity (Table 1 ).

Referring to Table 1, halloysite and kaolinite were the dominant minerals within Karangnunggal kaolin. This clay mineral is similar to Cameroon kaolin (china clay) that can be used for manufacturing the body a white ceramic types for both hard and soft porcelain (Berry et al., 2006). Halloysite can reduce the combustion temperature in the sintering process of ceramic (Murray, 2007).

Chemical analysis showed that Karangnunggal kaolin comprised several oxides such as $\mathrm{SiO}_{2}=65.78 \%, \mathrm{Al}_{2} \mathrm{O}_{3}=19.55 \%$, $\mathrm{Fe}_{2} \mathrm{O}_{3}=0.90 \%$ (Table 2). The $\mathrm{SiO}_{2}$ and $\mathrm{Al}_{2} \mathrm{O}_{3}$ belonged to the main compound in ceramic material. The compound of $\mathrm{Fe}_{2} \mathrm{O}_{1}$ may reduce the ceramics brightness, so its content should be less than 1\% (Celik, 2010).

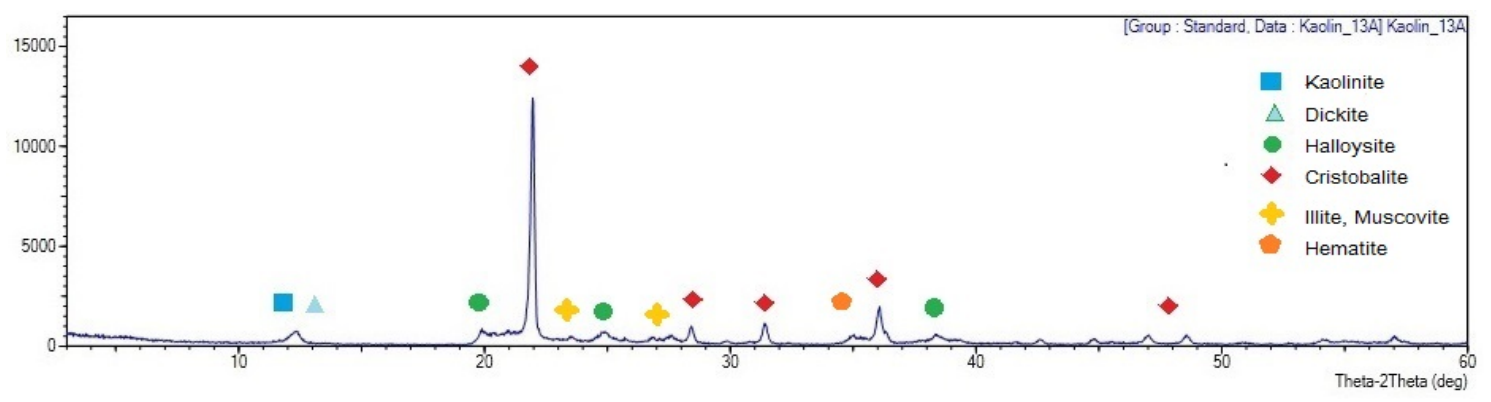

Figure 4. XRD diffractogram of Karangnunggal kaolin

Table 1. Quantitative mineral of Karangnunggal kaolin

\begin{tabular}{clcc}
\hline No & Mineral & Formula & Content (\%) \\
\hline 1 & Cristobalite & $\left(\mathrm{SiO}_{2}\right)$ & 45.0 \\
2 & Halloysite & $\left(\mathrm{Al}_{2} \mathrm{Si}_{2} \mathrm{O}_{5}[\mathrm{OH}]_{4}\right)$ & 25.2 \\
3 & Kaolinite & $\left(\mathrm{Al}_{2} \mathrm{Si}_{2} \mathrm{O}_{5}[\mathrm{OH}]_{4}\right)$ & 8.8 \\
4 & Dickite & $\left(\mathrm{Al}_{2} \mathrm{Si}_{2} \mathrm{O}_{5}[\mathrm{OH}]_{4}\right)$ & 6.9 \\
5 & Muscovite & $\left.(\mathrm{KF})_{2}\left(\mathrm{Al}_{2} \mathrm{O}_{3}\right)_{3}\left(\mathrm{SiO}_{2}\right)_{6}\left(\mathrm{H}_{2} \mathrm{O}\right)\right\}$ & 8.5 \\
6 & Illite & $\left\{\left(\mathrm{K}, \mathrm{H}_{3} \mathrm{O}\right)(\mathrm{Al}, \mathrm{Mg}, \mathrm{Fe})_{2}(\mathrm{Si}, \mathrm{Al})_{4} \mathrm{O}_{10}(\mathrm{OH})_{2},\left(\mathrm{H}_{2} \mathrm{O}\right)\right\}$ & 4.8 \\
7 & Hematite & $\left(\mathrm{Fe}_{2} \mathrm{O}_{3}\right)$ & 0.8 \\
\hline
\end{tabular}

Table 2. Result of chemical analysis for Karangnunggal kaolin

\begin{tabular}{ccccc}
\hline No & Oxides & Unit & \% Weight & Method \\
\hline 1 & $\mathrm{SiO}_{2}$ & $\%$ & 65.78 & Gravimetric \\
2 & $\mathrm{TiO}_{2}$ & $\%$ & 0.64 & Spectrophotometry \\
3 & $\mathrm{Al}_{2} \mathrm{O}_{3}$ & $\%$ & 19.55 & Titration \\
4 & $\mathrm{Fe}_{2} \mathrm{O}_{3}$ & $\%$ & 0.90 & Atomic Absorption Spectroscopy (AAS) \\
5 & $\mathrm{MnO}$ & $\%$ & 0.01 & AAS \\
6 & $\mathrm{MgO}$ & $\%$ & 0.02 & AAS \\
7 & $\mathrm{CaO}$ & $\%$ & 0.12 & AAS \\
8 & $\mathrm{Na}_{2} \mathrm{O}$ & $\%$ & 1.54 & AAS \\
9 & $\mathrm{~K}_{2} \mathrm{O}$ & $\%$ & 0.60 & AAS \\
10 & $\mathrm{P}_{2} \mathrm{O}_{5}$ & $\%$ & 0.56 & Spectrophotometry \\
11 & $\mathrm{H}_{2} \mathrm{O}^{-}$ & $\%$ & 0.66 & Gravimetric \\
12 & $\mathrm{H}_{2} \mathrm{O}^{+}$ & $\%$ & 0.98 & Gravimetric \\
13 & $\mathrm{SO}_{3}$ & $\%$ & 0.35 & Gravimetric \\
14 & $\left(\mathrm{LOI}^{2}\right.$ & $\%$ & 8.29 &
\end{tabular}


Compared to $\mathrm{SiO}_{2}$ and $\mathrm{Al}_{2} \mathrm{O}_{3}$ compounds counted by Suhala and Arifin (1997) that was around $46.54 \%$ and $39.50 \%$, it may be said that Karangnunggal kaolin was low level kaolin. However, the content of alkali $\left(\mathrm{K}_{2} \mathrm{O}\right.$ and $\left.\mathrm{Na}_{2} \mathrm{O}\right)$ at $2.14 \%$ is almost the same as kaolin from Jebus West Bangka, at which such kaolin can be made for decorative ceramic using casting or slip casting system (Subari and Primasari, 2013). High content of $\mathrm{SiO}_{2}$ and low content of $\mathrm{Al}_{2} \mathrm{O}_{3}$ affect to decreasing dry shrinkage and shrinkage of fuel when burned at temperature of $1,050^{\circ} \mathrm{C}$ (Hartono, 1993).

$\mathrm{SiO}_{2}$ and $\mathrm{Al}_{2} \mathrm{O}_{3}$ oxides in ceramic materials serves as a framework/filler of ceramic body. The content of $\mathrm{Fe}_{2} \mathrm{O}_{3}$ and $\mathrm{TiO}_{2}$ provides a certain color on the ceramic body. The oxides of alkali can serve to lower the melting temperature in the combustion process while loss of ignition (LOI) which consist of organic compounds and water, affect the nature of the plasticity of kaolin (Septawendar et al., 2007).

$\mathrm{Fe}_{2} \mathrm{O}_{3}$ can provides the unwanted color, on white ceramic namely beige brown (Choudhary et al., 2012). However, $\mathrm{Fe}_{2} \mathrm{O}_{3}$, $\mathrm{CaO}$, and $\mathrm{MgO}$ as impurities of Karangnunggal kaolin do not affect the color of white ceramic body after a burning process at high temperatures (above $1,050^{\circ}$ C). The iron oxide $\left(\mathrm{Fe}_{2} \mathrm{O}_{3}\right)$ will also affect degree of whiteness and serves as one of the parameters to determine the kaolin for ceramic raw materials. If the content is below $1.0 \%$, when the material is burned at high temperatures (above $900^{\circ} \mathrm{C}$ ) will appear white. On the contrary; if the $\mathrm{Fe}_{2} \mathrm{O}_{3}$ content above $1.0 \%$ it will yield cream color after burning process.

Yellowish brown color of impurities iron compound will reduce the whiteness, inhibit proliferation properties of optical fibers, lower the translucent nature of the product, and limit use in the industry. Luévanos et al. (2011) examined concentrations of iron contained in kaolin. The study discusses the reduction of iron content in kaolin influenced by oxalic acid concentration. Iron content in kaolin will decreases with the increase of oxalic acid concentration. Decreasing iron content up to $0.5 \%$ will not affect the color of the white ceramic body (Lee et al., 2007). Based on whiteness analysis (Table 3 ) it is known that the quality of Karangnunggal kaolin has a degree of $48.05 \%$. This means that Karangnunggal kaolin has lower quality.

Table 3. Result of whiteness analysis for Karangnunggal kaolin

\begin{tabular}{ccc}
\hline No & Sample & Whiteness (\%) \\
\hline 1 & Kaolin & 48.05 \\
2 & Kaolin $+5 \%$ Citric & 51.48 \\
acid & \\
\hline
\end{tabular}

After using a mixture solution of $5 \%$ citric acid, kaolin whiteness turns into $51.48 \%$ or increased to whiteness of $3.43 \%$. To improve kaolin whiteness can actually be conducted by magnetic ferro filter. The increase reaches above $50 \%$ (Subari and Wahyudi, 2014). The $51.48 \%$ of Karangnunggal kaolin whiteness is lower than that of whiteness from Bangka kaolin that retains $65 \%$. Based on the results of the burning test fuel at $1.400^{\circ} \mathrm{C}$ shows that whiteness of $51.48 \%$ within Karangnunggal kaolin did affect the color after it burned at high temperatures. When combustion temperature is lowered, the color after the burning process do not change in atmospheric conditions.

The water content of the Karangnunggal kaolin sample, analyzed by moisture content method, is $4.75 \%$. Such a figure is suitable for ceramic raw materials for either porcelain, solids pottery or non solid pottery (Nuntiya and Prasanphan, 2006). Meanwhile, results from grain size analysis show that the amount of $>2$ micron is $56.30 \%$. The results are quite good and can be used as raw materials in the manufacturing of glaze and ceramics body (Nugroho et al., 2000).

Kaolin grains size will affect the flexural strength of ceramic products; the larger the grain size of the material, the more reduced the bending strength (Johnson et al., 2012). Kaolin with grain size $\leq 2 \mu \mathrm{m}$ is estimated to produce a dry flexural strength and flexural strength. Large grains size will affect the flexural strength of ceramic products, while the grain size result in smaller flexural strength of the ceramic body (Johnson et al., 2012). Kaolin with a grain size of $<2 \mu \mathrm{m}$ retaining quantity of $56.30 \%$ are less plastic. As a result, both dry flexural strength and thermal flexural strength of the ceramic body will save fuel if incinerated at 1,200- 
$1,300^{\circ} \mathrm{C}$. Yet the kaolin with similar size but its quantity is bigger than $80 \%$ normally retains plasticity and high dry strength characters. As a result, such a kaolin can be used for stoneware-ceramics type (Johnson et al., 2012). The fact that the large grain size fraction of $<2 \mu \mathrm{m}$ is less and the content of $\mathrm{SiO}_{2}$ is high enough (65.78\%), means that Karangnunggal kaolin is less plastic. To increase the Karangnunggal kaolin plasticity, it can be added ball clay materials.

After burning at $1,400^{\circ} \mathrm{C}$, the kaolin showed white in color and it is almost melt rather dense as well as non-porous. Referring to such characters Karangnunggal kaolin can be used as a raw material for manufacturing white ceramic products as porcelain body to stoneware. According to Johnson et al. (2012) kaolin with such properties can also be used for porous ceramic, but it needs to be mixed with sawdust material. After burning process $1,050^{\circ} \mathrm{C}$, seven specimens of Karangnunggal kaolin (KK1 to KK7) showed dry shrinkage of $7.54 \%$, firing shrinkage of $2.48 \%$, dry flexural strength of $18.29 \mathrm{~kg} / \mathrm{cm}^{2}$, and thermal flexural strength in of $47.58 \mathrm{~kg} / \mathrm{cm}^{2}$ (Table 4 ).

The total amount of shrinkage factors, as a combination of dry shrinkage $(7.54 \%)$ and firing shrinkages $(2.48 \%)$, is $10.02 \%$. This result is smaller compared to the amount of dry and firing shrinkages of ball clay that is $10.50 \%$ (Septawendar et al., 2007). The fact that the average value of dry shrinkage is $7.54 \%$, shows that this kaolin has plastic properties. Compared to kaolin studied by El Quahabi et al. (2014) that has less plastic characters, the plasticity of Karangnunggal kaolin is much better because the dry shrinkage of El Quahabi kaolin is around 2-6 $\%$.
Referring to firing shrinkage value, Karangnunggal kaolin has firing shrinkage of $2.48 \%$. It is better than the kaolin studied by Baccour et al. (2009). Such kaolin is burned at temperature of $1,050^{\circ} \mathrm{C}$ producing firing shrinkage of $3.12 \%$ (KK6). The differences in the amount of firing shrinkage is due to the different content of the alumina. Kaolin studied by Baccour et al. (2009) has 18.8\% of alumina. It is lower than that of Karangnunggal kaolin with alumina content of $19.55 \%$.

The average value of dry flexural strength of Karangnunggal kaolin is low $\left(18.29 \mathrm{~kg} / \mathrm{cm}^{2}\right)$, because the $X-R D$ semi-quantitative data showed cristobalite content is bigger than that of clay minerals such as halloysite, kaolinite and dickite. Similar condition occurred to the average value of thermal flexural strength of $47.58 \mathrm{~kg} / \mathrm{cm}^{2}$. Such a strength $\left(47.58 \mathrm{~kg} / \mathrm{cm}^{2}\right)$ is also low, because most kaolin when burned at temperatures $1,050^{\circ} \mathrm{C}$ is still in metakaolin form and mullite did not occur. Mullite can increase mechanical strength of the ceramic body, especially when it is in needle shape (Leonard and Kjell, 2004).

Karangnunggal kaolin including types of disordered kaolinite, will form mullite and can improve the mechanical strength after being burned at temperature above $1,200^{\circ} \mathrm{C}$ (Kamseu et al., 2007). After the burning process at a temperature above $1.100^{\circ} \mathrm{C}$, kaolin will change to mullite and cristobalite (Septawendar et al., 2007). Its reaction can be seen in equation 1.

However, Georges-Ivo et al. (2008) stated that kaolin was already changed into mullite the burning kaolin at $1,050^{\circ} \mathrm{C}$. Its reaction can be seen in equation 2 . $\begin{array}{lll}{\left[\mathrm{M}_{\mathrm{x}} \mathrm{O}_{\mathrm{y}}\right]\left(\mathrm{aAl}_{2} \mathrm{O}_{3} \mathrm{bSiO}_{2}\right) \mathrm{CH}_{2} \mathrm{O}} & \rightarrow \quad & 3 \mathrm{Al}_{2} \mathrm{O}_{3} 2 \mathrm{SiO}_{2}+\mathrm{SiO}_{2}+\mathrm{MxOy}\left[\mathrm{SiO}_{2} \cdot 2 \mathrm{Al}_{2} \mathrm{O}_{3}\right] \\ \text { mullite phase glass phase } & & \mathrm{M}_{\mathrm{x}} \mathrm{O}_{\mathrm{y}}=\text { alkali which contained in clay }\end{array}$

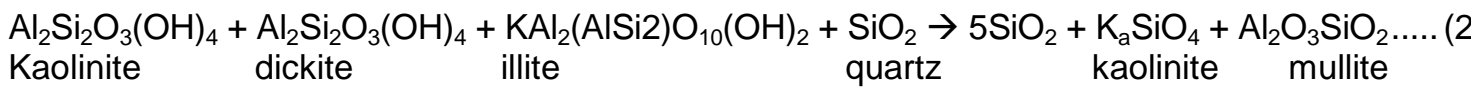

Kaolinite dickite illite quartz kaolinite mullite


Table 4. Ceramics properties for Karangnunggal kaolin

\begin{tabular}{ccccc}
\hline Code & Dry shrinkage (\%) & $\begin{array}{c}\text { Firing shrinkage } \\
(\%)\end{array}$ & $\begin{array}{c}\text { Dry flexural strength, } \\
\left(\mathrm{kg} / \mathrm{cm}^{2}\right)\end{array}$ & $\begin{array}{c}\text { Thermal flexural } \\
\text { strength }\left(\mathrm{kg} / \mathrm{cm}^{2}\right)\end{array}$ \\
\hline KK1 & 7.68 & 2.60 & 16.89 & 47.10 \\
KK2 & 7.10 & 3.05 & 18.67 & 46.25 \\
KK3 & 7.72 & 1.96 & 16.98 & 49.17 \\
KK4 & 7.84 & 2.14 & 17.53 & 45.89 \\
KK5 & 8.03 & 1.98 & 20.12 & 49.37 \\
KK6 & 6.95 & 3.12 & 19.45 & 46.92 \\
KK7 & 7.47 & 2.53 & 18.37 & 48.35 \\
\hline Average & 7.54 & 2.48 & 18.29 & 47.58 \\
\hline
\end{tabular}

Combustion of kaolin at high temperatures will produced different color due to differences in $\mathrm{Fe}_{2} \mathrm{O}_{3}$ content. Kaolin contain 19-26 \% $\mathrm{Al}_{2} \mathrm{O}_{3}$ and 1.5-3 \% $\mathrm{Fe}_{2} \mathrm{O}_{3}$ and after burned at high temperatures $\left(>900^{\circ} \mathrm{C}\right)$ produced material with creamy yellowish or brownish in color (Subari and Wenas, 2007; Ramaswamy and Raghavan, 2011). Karangnunggal kaolin containing $19.55 \%$ $\left(\mathrm{Al}_{2} \mathrm{O}_{3}\right)$ and $0.90 \%\left(\mathrm{Fe}_{2} \mathrm{O}_{3}\right)$, and burned at $1,050^{\circ} \mathrm{C}$ produced light beige kaolin due to its iron content is $<1.5 \%$, (0.90 \%).

\section{CONCLUSIONS AND SUGGESTION}

Based on characterization of Karangnunggal kaolin, the material can be used for white ceramic products such as sanitary, ceramic tiles and insulation. Low composition of $\mathrm{Fe}_{3} \mathrm{O}_{4}$ in Karangnunggal kaolin $(0.90 \%)$ is an advantage as it can be used for white ceramic without affecting the brightness of the colors when it is burned at high temperatures $\left(\geq 1,050^{\circ} \mathrm{C}\right)$. To increase ceramics strength, it is suggested to mix kaolin with mullite. Drilling exploration needs to be conducted in terms of assessing the potential kaolin deposit.

\section{ACKNOLEDGEMENTS}

The author would like acknowledge to Ir. Dewi Fatimah, Dra. Lenny Marilyn Estiaty, and Ir. Sri Indarto for their valuable insight and criticism which improved the quality of this manuscript. Also acknowledge to Yoyo Suparyo and Bejo, of ceramics laboratory for their help during the research.

\section{REFERENCES}

Ajayi, O.A., and Adefila, S.S., 2012. Comparative study of chemical and biological methods of beneficiation of Kankara kaolin, International Journal of Scientific and Technology Research, vol. 1, issue 8, p. 13-18.

Baccour, H., Medhioub, M., Jamoussi, F., and Mhiri, T., 2009. Influence of firing temperature on the ceramic properties of Triassic clays from Tunisia. Journal of Materials Processing Technology. p. 2812-2817.

Berry, R.W., Bergaya, F., and Lagaly, G., 2006. Teaching clay science: a great perspecive, handbook of clay science, Developments in Clay Science, Departement of Geological Science, San Diego State University, San Diego, USA. vol. 1, p. 1183-1195.

Boch, P., and Niepce, J.C., 2007. Ceramik Materials: Process, Properties and Applicatioans, ISTE LTd., London United Kingdom. 563 p.

Cases, J.M., Cunin, P., Grillet, Y., Poinsignon, C., and Yvon, J., 1986. Methods of analysing morphology of kaolinites: relations between crystallographic and morphological properties, Clay Minerals, p. 55-68.

Celik, H., 2010. Technological characterization and industrial apllication of two Turkish clay for the ceramic industry, Applied Clay Science, vol.50, issue 2, p. 245254.

Choudhary, R.P., Sheoran, A.S., and Trivedi, S.K., 2012. A small kaolin beneficiation unit state of art, International Journal of Earth Sciences and Engineering, p. 775-781. 
El Quahabi, M., Daoudi, L., De Vleeschouwer, F., Bindler, R., and Fagel, N., 2014. Potentiality of clay raw materials from Northern Morocco in ceramic industry: Tetouan and Meknes Areas, Journal of Minerals and Materials Characterization and Engineering, p. 145-159.

Fialips, C.I., Petit, S., Decarreau, A., 1999. Influence du $\mathrm{pH}$, du materiau de de'part et de la dure'e de synthe'se sur la cristallinite' de la kaolinite, Compte Rendu Académie des Sciences, Paris, p. 515-520.

Georges-Ivo, E., Ekosse and Antonie, F., and Mulaba-Bafibiandi, 2008. Mineral thermochemistry of bentonite and kaolin related to their possible application in the ceramic industry, Journal of Applied Sciences, 8 (22), p. 4145-4151.

Hartono, Y.M.V., 1993. Bahan mentah untuk pembuatan keramik, Balai Besar Penelitian dan Pengembangan Industri Keramik, Departemen Perindustrian, Bandung. p. 18-69 (unpublished).

Johnson, K.E., Damoah, L., Delali, Y.B., David, D.A., and Tetteh, D., 2012. Development of porous ceramic bodies from kaolin deposits for industrial applications, Journal of Applied Clay Science, p. 3136.

Kamseu, E., Leonelli, Boccaccini, D.N., and Veronesi, P., 2007. Characterisation of porcelain compositions using two china clays from Cameroon, Ceramics International, 33, p. 851-857.

Lee, S.O., Tam, T., Byoung, H., Seong, J.K., and Myong, J.K., 2007. Dissolution of iron oxide using oxalic acid, Journal Hydrometallurgy, 87, p. 91-99.

Leonard, D.A., and Kjell, W., 2004. Ceramic properties of Pugu kaolin llays, part 2: effect of phase composition on flexural strength, Bulletin Chemical Society of Ethiopia, 18 (1), p. 7-16.

Luévanos, A.M., Rodríguez-Delgado, M.G., Uribe-Salas, A., Carrillo-Pedroza, F.R., and Osuna-Alarcón, J.G., 2011. Leaching kinetics of iron from low grade kaolin by oxalic acid solutions, J. Appl. Clay Sci. 51, p. 473-477.

Murray, H.H., 2007. Applied clay mineralogy: occurrences, processing and aplication of kaolin, bentonites, palygorskite, sepiolite, and common clays,
Departement of Geological Sciences, Indiana University, Bloomington, USA, $180 \mathrm{p}$.

Nugroho, T., Sundari, K.N., and Subari, 2000. Penerapan breksi vulkanik tuff Desa Subagan Kecamatan Alampura, Kabupa-ten Karang Asem, Propinsi Bali sebagai bahan glasir, Prosiding Kolokium Pertambangan 2000, Direktorat Jenderal Pertambangan Umum, Puslitbang Teknologi Mineral, Bandung. p. 119-126.

Nuntiya, A. and Prasanphan, S., 2006. The rheological behavior of kaolin suspensions, Journal Science, Chiang Mai. 33 (3), p. 271-281.

Ramaswamy, S., and Raghavan, P., 2011. Significance of impurity mineral identification in the value addition of kaolin - a case study with reference to an acidic kaolin from India, Journal of Minerals and Materials Characterization and Engineering. vol. 10, no. 11, p. 1077-1025.

Septawendar, R., Nuryanto, and Subari, 2007. Karakterisasi lempung Tanjung Beringin Sumatera Utara dan pemanfaatannya untuk badan keramik stoneware. Jurnal Keramik Dan Gelas Indonesia, Balai Besar Keramik, vol. 16 no. 1, p. 26-35.

Septawendar, R., Nuryanto, Suhanda, and Wahyudi, K., 2007. Sifat fisik lempung Tanjung Morawa dalam transformasi fasa mineral berdasarkan investigasi difraksi Sinar X, Jurnal Riset Geologi \& Pertambangan, jilid 17, no. 1, p. 11-19.

Subari and Primasari, B., 2013. Percobaan pembuatan produk keramik hias dan ubin yang menggunakan bahan tunggal clay dari Kabupaten Belitung Barat, Prosiding Seminar Nasional Keramik XII, Balai Besar Keramik Bandung. p. 32-43.

Subari and Wenas, RIF., 2007. The change of chemical and physical properties of clay, Indonesian Mining Journal, vol. 10, no.09, p. 44-53.

Subari and Wahyudi, T., 2014. Improving tapin kaolin quality for whiteware ceramic, Indonesian Mining Journal, vol. 17, no. 2, p. 87-97.

Suhala, S., and Arifin, M., 1997. Bahan galian industri, Pusat Penelitian Teknologi Mineral, Bandung. p. 215-229. 